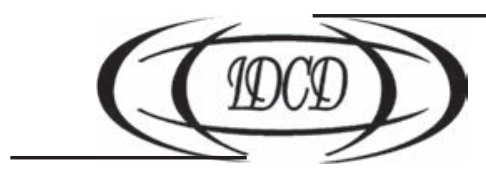

doi: $10.15407 /$ dse2015.03.016

УДК 37.018.1:316.362.1(477)

\title{
В.П. ДУМАНСЬКА
}

канд. екон. наук, старш. наук. співроб.

Інститут демографії та соціальних досліджень

ім. М.В. Птухи НАН України

E-mail: vita_dumanska@ukr.net

\section{ВІДПОВІДАЛЬНЕ БАТЬКІВСТВО: ТЕОРЕТИЧНИЙ АСПЕКТ}

У статті поглиблено теоретичні підходи до визначення відповідального батьківства, проаналізовано сучасні тенденції у батьківстві в Україні та їх демографічні наслідки, визначено основні виміри та складові відповідального батьківства. Суть відповідального батьківства розкрито в контексті етичних, правових, соціальних та економічних передумов. Складовими відповідального батьківства є відповідальна репродуктивна та вітальна поведінка, відповідальне ставлення до вагітності та пологів, відповідальне виховання дітей та позитивні родинні стосунки. Запропоновано систему аналітичних індикаторів для оцінки динаміки відповідального ставлення до планування, народження та виховання дітей.

Ключові слова: відповідальне батьківство, концепція відповідального батьківства, тенденції у батьківстві, прояви відповідального батьківства, відкладення дітонародження, демографічна криза.

\section{В.П. Думанская}

канд. экон. наук, старш. науч. сотр.

Институт демографии и социальных исследований

им. М.В. Птухи НАН Украины

E-mail: vita_dumanska@ukr.net

\section{ОТВЕТСТВЕННОЕ РОДИТЕЛЬСТВО: ТЕОРЕТИЧЕСКИЙ АСПЕКТ}

В статье углублены концептуальные подходы к определению ответственного родительства. Мы рассматриваем родительство как интегральное понятие, отражающее равноправное участие мужчины и женщины в воспитании детей в современных семьях. Оно предполагает как материнство (рождение и воспитание детей женщиной), так и участие отиа в воспитании детей. На наш взгляд, ответственное родительство - это платформа, на основе которой формируются взвешенная потребность в детях, необходимые знания для воспитания и развития детей, партнерские отношения между родителями и детьми в течение жизни.

В работе проанализированы современные тенденции в родительстве в Украине и их демографические последствия, определено, каким образом повышение возраста вступления в брак и возраста рождения детей, уменьшение средней продолжительности брака, рост экономической активности женщин и постепенный рост роли отца в воспитании детей влияют на формирование ответственного подхода $\kappa$ родительству.

Нами определены основные измерения и составляющие ответственного родительства. Суть ответственного родительства раскрыта в контексте этических, правовых, социальных и экономических предпосылок. Составляющие ответственного родительства: ответственное репродуктивное и

(с) ДУМАНСЬКА В.П., 2015 
витальное поведение, ответственное отношение к беременности и родам, ответственное воспитание детей и налаживание положительных семейных отношений.

В статье предложена система аналитических индикаторов для оценки динамики ответственного отношения к планированию, рождению и воспитанию детей.

Ключевые слова: ответственное родительство, предпосылки ответственного родительства, тенденции в родительстве, проявления ответственного родительства, откладывание деторождения, демографический кризис.

Vita Dumanska

$\mathrm{PhD}$, Senior Researcher

Ptoukha Institute for Demography and Social Studies

of the National Academy of Sciences of Ukraine

01032, Kyiv, blvd. Taras Shevchenko, 60

E-mail: vita_dumanska@ukr.net

\section{RESPONSIBLE PARENTHOOD: THEORETICAL ASPECT}

The paper extends conceptual approaches to the definition of the responsible parenthood. We interpret parenting as an integral concept that reflects the equal participation of men and women in child-rearing in modern families; it includes both maternity and paternity. Responsible parenthood is a platform which forms the conscious need for children, the necessary knowledge for the child-rearing and development, partnerships between parents and children during their lifetime.

The author analyzes the current trends in parenthood in Ukraine and their demographic impact, determines how the increasing of the age at marriage and the age of the birth of children, reducing the average duration of marriage, the increasing of women's economic activity and a father's role in child-rearing affect the formation of a responsible approach to parenthood.

We have identified the main components and the measurement indicators of the responsible parenthood. The essence of responsible parenthood is disclosed in the context of the ethical, legal, social and economic framework. The components of responsible parenthood are vital and responsible reproductive behavior, responsible attitude to pregnancy and childbirth, responsible parenting and the establishment of positive family relationships.

The author suggests a system of analytical indicators for the assessment of a responsible attitude to family planning, childbirth and parenthood.

Key words: responsible parenthood, concept of responsible parenthood, trends in parenting, manifestations of responsible parenthood, postponing of childbearing, demographic crisis.

Постановка проблеми. У науковій спільноті активно дискутують проблему падіння народжуваності, зменшення дітності у сім'ях, трансформації інституту шлюбу, поширення неповних сімей тощо. Здійснено чимало досліджень, спрямованих на осмислення цих явищ, причин їх виникнення та можливих соціально-демографічних наслідків. Проте досі не сформовано єдиної цілісної концепції, яка могла б вичерпно пояснити наявні тренди, та дала б змогу спрогнозувати, яким буде перебіг процесів народжуваності та шлюбно-сімейної динаміки у найближчому майбутньому. Ми переконані, що для суттєвих зрушень у вивченні цих процесів необхідне поглиблення концептуальних підходів до дослідження феномену відповідального батьківства.

Концептуальне підгрунтя аналізу відповідального батьківства перебуває лише на стадії формування, проте наявний теоретичний інструментарій нині дає змогу пояснити зниження «попиту» на дітей, зміщення фокусу із чисельності дітей на їх якісні характеристики, потребу інвестування у людський капітал дитини, причини виникнення свідомої бездітності та ін.

Актуальність дослідження. Актуальність проблеми є безумовною в контексті зниження народжуваності, погіршення шлюбно-сімейної динаміки, поширення 
неповних сімей, зростання масштабів сирітства, наявності випадків жорстокого поводження з дітьми тощо. Не менш важливими є медико-соціальні аспекти цієї проблеми, пов'язані з культурою статевого виховання, утвердженням активної самозбережувальної поведінки, необхідністю соціальної підтримки молоді.

Філософія відповідального батьківства має стати основою як соціальних практик, так і сучасної сімейної політики, забезпечити їі орієнтацію на задоволення інтересів батьків і дітей, на розвиток людського та соціального капіталу.

Мета статті полягає в поглибленні концептуальних засад дослідження відповідального батьківства та визначенні індикаторів для його моніторингу у контексті сучасної соціально-демографічної ситуації. Задля досягнення цієї мети у ході роботи було уточнено зміст поняття «відповідальне батьківство», визначено форми його прояву та запропоновано показники для оцінювання зрушень у цій сфері.

Аналіз публікацій. Проблема відповідального батьківства є комплексною, адже перебуває на межі соціології, психології, демографії та економіки. Одним із перших, хто використав економічний інструментарій для пояснення батьківської поведінки, був американський економіст Г. Бекер (G. Becker). Саме він висунув припущення про існування «попиту на дітей» і розглядав дітей як одну з інвестиційних альтернатив: батьки можуть інвестувати у дитину, а можуть ці ж кошти та час спрямувати на свій особистий розвиток чи на інші інвестиційні проекти.

Питання батьківства досить активно вивчаються психологами, соціологами та педагогами. Українські науковці проблеми батьківства вивчали в основному в контексті шлюбно-сімейних процесів і соціальної політики. Особливий внесок у вивчення цього питання зроблено I. Курило (I. Kurylo), Б. Крімером (B. Krimer), Е. Лібановою (E. Libanova), Л. Слюсар (L. Sliusar) [2, 5]. Водночас цей феномен є малодослідженим та потребує грунтовнішого вивчення, адже концепція відповідального батьківства може стати основою для розробки ефективної сімейної політики.

Виклад основного матеріалу. Стрімке падіння народжуваності в Європейських країнах у другій половині XX ст. пов’язують з другим демографічним переходом. Сім'ям важко наважитися на народження дитини, домінують однодітні сім'ї, набирає поширення свідома бездітність. Падіння «попиту» на дітей зумовлене посиленням прагнення молодих людей до самореалізації (здобуття освіти, кар'єра, дозвілля, налагодження особистих стосунків тощо) [11].

У сучасному соціумі суттєво зменшилась роль дітей: народження дітей більше не пов’язане з економічною необхідністю, потребою допомоги по господарству та матеріального забезпечення у старості, також поступово втрачається роль релігійних заборон. Поряд з цим відбувається трансформація образу дитини: для батьків вона перетворюється на об’єкт любові, обожнювання та інвестицій (як фінансових, так і емоційних), сім’ї стають дітоцентричними. Тобто батьківство із простого відтворення та економічної потреби перетворюється у реалізацію соціально-психологічної потреби подружжя, поступово відбувається утвердження відповідального батьківства.

У статті ми використовуємо інтегральне поняття «батьківство», яке відображає рівноправну участь чоловіка і жінки у вихованні дітей у сучасних родинах (з англ. parenthood), тобто воно включає як материнство (народження та виховання дітей жінкою), так і участь батька у вихованні дітей.

У літературі сутність батьківства як багатогранного явища розглядається як:

- соціальний інститут, який поєднує два інших інститути - материнство і батьківство (у вузькому розумінні); 
• діяльність батьків по догляду, матеріальному забезпеченню, вихованню, навчанню дитини;

• об’єктивний факт походження дитини від конкретних батьків, засвідчений актовим записом про народження в органах РАЦС;

- суб’єктивне відчуття людини себе батьком/матір'ю;

- кровна спорідненість між батьками і дитиною;

- усвідомлення батьками родинного зв’язку з дітьми [3].

Як свідчать дослідження, народження дитини для більшості людей є однією 3 найважливіших подій у житті [7]. Саме тому у ході вивчення феномену батьківства, окрім інституційних та нормативно-правових аспектів, потрібно враховувати й емоційну та психологічну складову: батьки народжують дітей для реалізації своєї психологічної потреби, прагнуть продовжити себе в дітях, дарувати любов.

Якщо батьківство - це більшою мірою біологічне та соціальне явище, то відповідальне батьківство - вияв індивідуальної та соціальної відповідальності. Адже сам факт наявності дітей не означає, що батьки відповідально виконують свої батьківські функції. Компонент відповідальності у батьківстві має дуалістичний характер: з одного боку батьки відповідальні перед суспільством за виховання його нових членів, з іншого - це вияв особистої соціальної відповідальності.

Згідно з методологією UNISEF, відповідальне батьківство передбачає безпечне фізичне середовище, нагляд за дітьми та їхньою поведінкою, сприяння розвитку їх соціально-емоційних та когнітивних компетенцій, скерування та підтримку у повсякденному житті [4]. За логікою цього підходу, відповідальне батьківство охоплює лише виховання дітей, тоді як ми розглядаємо його значно ширше - з врахуванням етапу, що передує народженню дитини, та підтримки сімейних стосунків із уже дорослими дітьми. Тобто, відповідальне батьківство передбачає такі стадії:

- планування та народження дітей;

- виховання та розвиток дітей;

- підтримання родинних стосунків.

Кожен із цих етапів є важливим як для батьків (реалізація батьківської функції), так і для фізичного та психоемоційного становлення дітей. Ці стадії є циклічними і повторюються у кожному черговому поколінні. Якщо батьки достатньо уваги приділяли вихованню дитини, прищепили їй сімейні цінності, докладали зусиль для підтримання родинних стосунків (спілкування з бабусями, дідусями та іншими родичами), діти з високою ймовірністю наслідуватимуть таку модель поведінки та більш охоче створюватимуть сім’ї й народжуватимуть дітей. Тобто, відповідальне ставлення до народження і виховання дітей істотно визначає дітородні орієнтації наступних поколінь.

Ключовою передумовою народження дітей є зрілість. Так, щоб стати батьками, чоловік і жінка повинні досягти фізіологічної зрілості, проте, щоб стати відповідальними батьками, вони мають досягти ще й психологічної, емоційної та соціальної зрілості.

На наш погляд, основними вимірами відповідального батьківства можна вважати етичний, правовий, економічний та соціальний, тоді як його базовими складовими $€$ репродуктивна та вітальна поведінка, виховання дітей, відповідальність за здорове потомство та особисті комунікації в дорослому віці (рис. 1). 


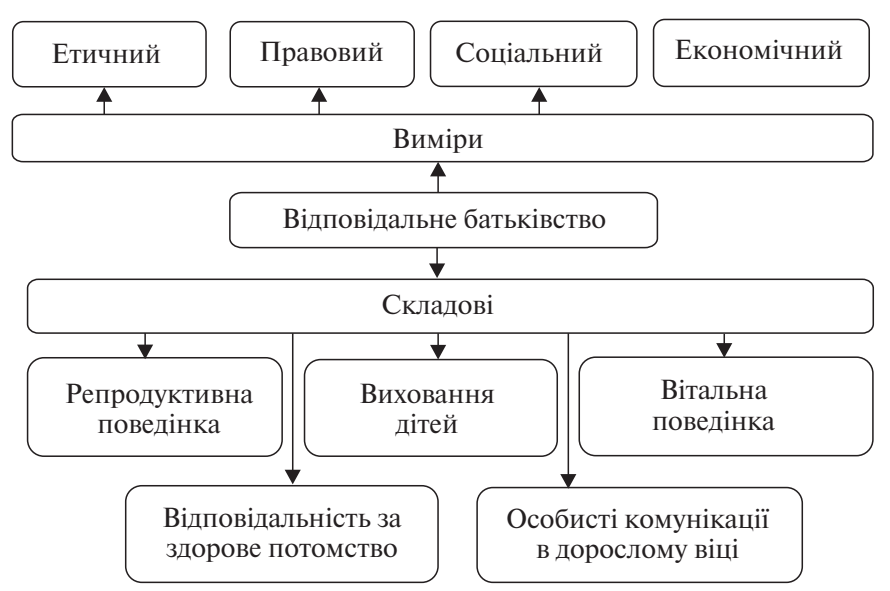

Рис. 1. Структура відповідального батьківства

Етичний вимір відповідального батьківства відображає як відповідальну репродуктивну поведінку, так і етичні аспекти виховання дітей. Відповідальне батьківство розпочинається з відповідального застосування контрацепції та свідомого обмеження дітонародження. Проте ці принципи досить часто конфліктують з релігійними нормами та деякими нормами суспільної моралі. 3 позицій відповідального батьківства, чоловік і жінка мають самостійно визначати оптимальну кількість дітей у сім’ї, керуючись психологічною потребою та можливістю забезпечити належні умови для розвитку дітей. Ще одним дискусійним компонентом є штучне переривання вагітності (аборт) як спосіб обмеження дітонародження. Суспільством аборти сприймаються неоднозначно, тоді як християнська мораль взагалі не визнає та засуджує таке рішення. На наш погляд, однією з передумов відповідального батьківства є усвідомлене використання контрацепції з метою дотримання бажаної чисельності дітей у сім’ї і забезпечення максимального рівня формування та розвитку людського капіталу дітей.

Правовий вимір відповідального батьківства відображає юридичні аспекти взаємодії батьків та дітей, їхні взаємні права та обов’язки. У Конституції України (ст. 51) визначено, що батьки зобов’язані утримувати дітей до їх повноліття, а повнолітні діти зобов'язані піклуватися про своїх непрацездатних батьків. В Україні досить часто батьки підтримують дітей не до настання повноліття або здобуття професійної освіти, а значно довше. Також часто трапляється так, що батьки-пенсіонери фінансово підтримують дітей та їхні сім’і. Західній моделі сімейних відносин такі стосунки не притаманні, адже батьки в основному підтримують дітей до повноліття, в старості батьки також не залежать від дітей, оскільки самостійно забезпечують себе за рахунок заощаджень та доходів від інвестицій, або ж цю функцію беруть на себе геріатричні інституції.

На наш погляд, соціальний вимір відповідального батьківства відображає специфіку соціальних взаємин між батьками та дітьми. Батьки є відповідальними за соціалізацію дітей, за підготовку їх до дорослого життя, прищеплення дітям загальнолюдських цінностей, набуття дітьми навичок, необхідних для повноцінного життя у соціумі. Народження дітей - це не лише задоволення власних психологічних потреб у дітях, це й відповідальність перед суспільством та державою за відтворення громадян. 
Економічний вимір відповідального батьківства передбачає створення батьками належних матеріальних умов для розвитку дитини. Відповідальне батьківство передбачає не лише забезпечення базових матеріальних потреб (їжа, одяг, житло), але й створення умов для повноцінного розвитку (додаткове навчання, спорт, відпочинок, лікування тощо). Народження та виховання дітей також має певні економічні наслідки, адже пов'язане зі зниженням рівня доходу батьків, які працюють. Так, американськими дослідниками встановлено, що серед жінок, які роблять перерву у трудовій діяльності у зв'язку з народженням дітей, спостерігається зменшення тривалості відпрацьованого часу та зниження заробітку, проте серед чоловіків, у яких $є$ діти, спостерігається збільшення доходів та кількості годин роботи [10].

Складовими відповідального батьківства вважаємо (рис. 1):

- відповідальну репродуктивну поведінку;

- відповідальність за здорових нащадків (відповідальне ставлення до вагітності та пологів);

- активну та позитивну вітальну поведінку;

- відповідальне виховання дітей (час, проведений з дітьми, створення належних матеріальних передумов для розвитку дитини (освіта, позашкільне виховання, спорт тощо));

- регулярні та позитивні комунікації в родині.

Реалізація батьківства може відбуватися за двома напрямами [3]. Згідно з першим напрямом народження дитини трактується як обмеження, в тому числі і як перешкода самореалізації. Другий стратегічний напрям вбачає у появі дитини нові можливості для родини. Якщо сім'я обирає першу стратегію, виникає дисгармонія між батьками та дітьми, втрачається радість від материнства (батьківства), від родинного спілкування, мало уваги приділяється навчанню та вихованню дітей, адже їх розглядають як «покарання», яке не дозволило батькам самореалізуватися професійно, досягти певного рівня матеріального добробуту тощо. Досить часто таке ставлення до дітей виникає в одиноких матерів, а також серед молодих людей, які надто рано стали батьками.

Другий стратегічний напрям $є$ уособленням відповідального батьківства, його реалізація відбувається через спільний розвиток, співпрацю, внаслідок чого створюються найкращі умови для розвитку особистості дитини і водночас виникає можливість для батьківської самореалізації (як особистої та професійної, так і у вихованні дітей).

Сьогодні надзвичайно важливо, щоб сім'ї свідомо обирали другу стратегію, адже такий підхід сприятиме підвищенню народжуваності, активному залученню батьків на ринок праці, розвитку і нарощенню людського капіталу. Для забезпечення домінування в українському соціумі цієї стратегічної орієнтації необхідним є розвиток інститутів дошкільного виховання (особливо по догляду за дітьми до трьох років), інститутів, які дають змогу поєднувати зайнятість та материнство (батьківство). Як свідчать дослідження, лише монетарними інструментами цього досягти не вдасться [1, 2].

Трансформацію сімейних цінностей у європейських країнах ілюструють такі дані. У країнах Східної Європи та Закавказзя (так само і в Україні) близько 80 \% населення переконане, що для повноцінного життя жінці потрібні діти, 70 \% вважають, що чоловіку для повної реалізації необхідні діти. У країнах Західної Європи ці переконання виражені слабше: так, у Польщі ці показники становлять 70 \% і 60 \% відповідно, тоді як у скандинавських країнах менше чверті населення вважає, що діти - необхідний компонент у житті жінки, у Фінляндії таких менше 12 \% (рис. 2). 

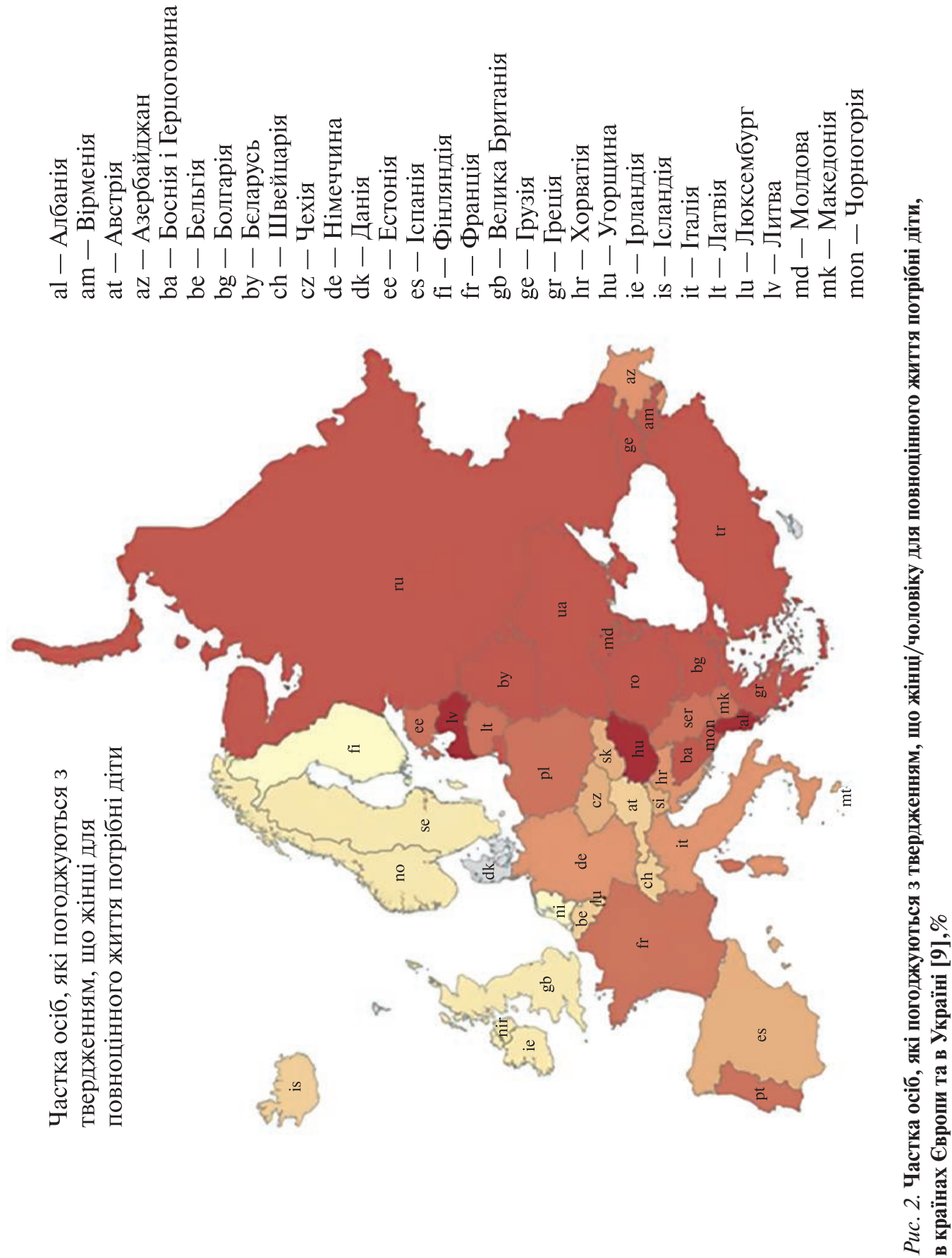


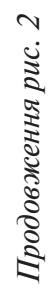
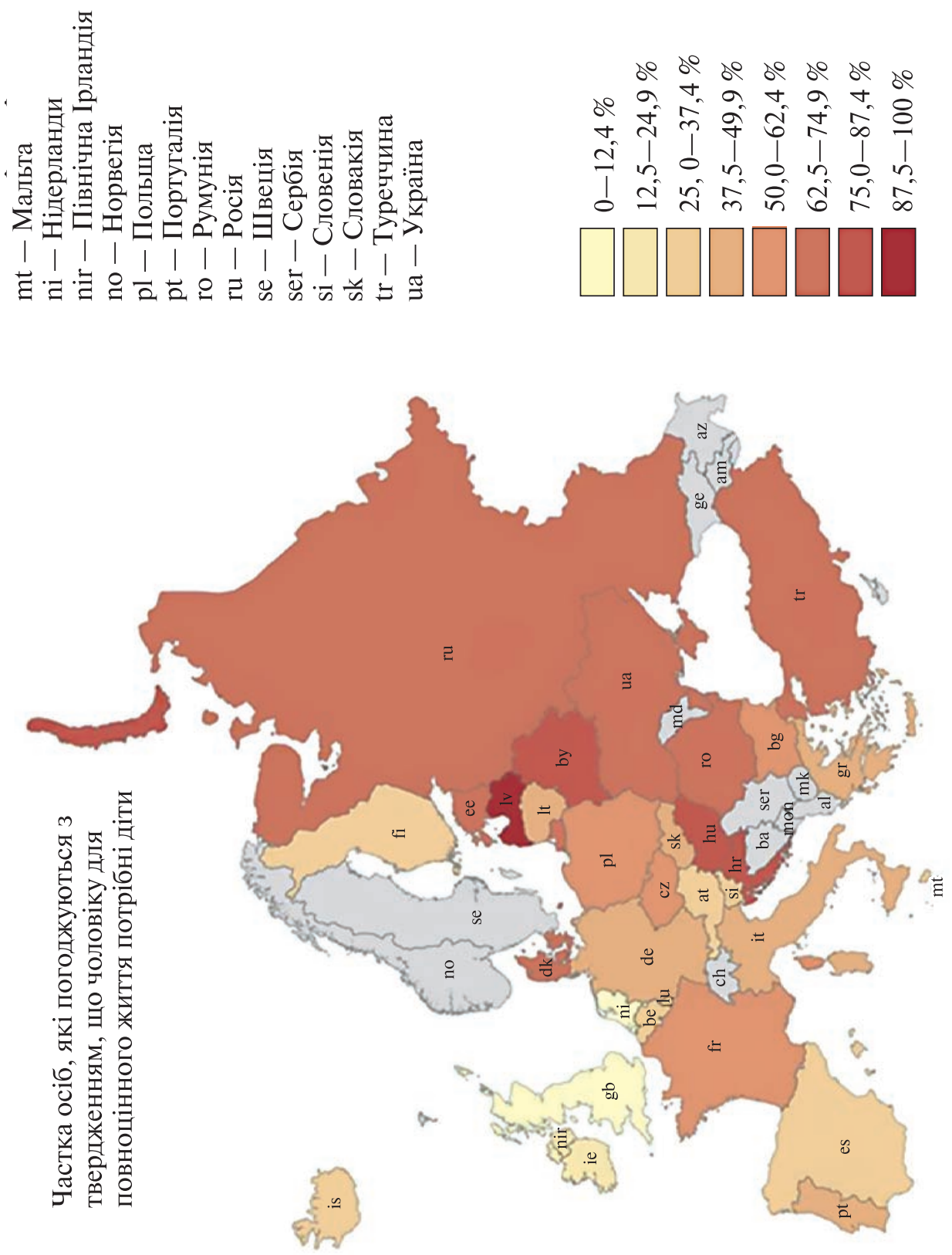
Якщо ж батьки зважуються на народження дітей, то вони докладають максимум зусиль для того, щоб виховати дитину та забезпечити їй певний рівень матеріального добробуту. Від 90 до 100 \% громадян Хорватії погоджуються з твердженням, що обов’язком батьків є зробити все можливе для власних дітей, навіть якщо це негативно позначиться на добробуті їх самих. У більшості Європейських країн цей показник складає 70-80 \%, тоді як в Україні - 60-70 \%. У Литві, Бєларусі, Греції менше 50 \% громадян готові пожертвувати своїм добробутом заради добробуту своїх дітей [6]. Це ще раз підтверджує високий рівень відповідальності батьків в Україні та країнах Східної Європи за долю своїх дітей, проте простежується інший тренд - усе менше батьків готові забезпечувати можливості розвитку своїм дітям за рахунок нехтування власними потребами (як матеріальними, так і духовними).

\section{Таблиия 1. Сучасні тенденції у батьківстві та їх соціально-економічні наслідки}

\begin{tabular}{|c|c|c|}
\hline $\begin{array}{c}\text { Сучасні тенденції } \\
\text { у батьківстві }\end{array}$ & Позитивний вплив & Негативний вплив \\
\hline $\begin{array}{l}\text { Підвищення віку вступу } \\
\text { в шлюб та народження } \\
\text { дітей }\end{array}$ & $\begin{array}{l}\text { • подружжя відзначається вищим } \\
\text { ступенем психологічної зрілості } \\
\text { та більш виважено підходить до } \\
\text { народження та виховання дітей; } \\
\text { • у сім'ях, в яких чоловік і жінка } \\
\text { є старшими, зазвичай кращі } \\
\text { матеріальні передумови для на- } \\
\text { родження та виховання дітей; } \\
\text { • такі пари, зазвичай, мають } \\
\text { вищий рівень освіти та усвідом- } \\
\text { люють необхідність розвитку та } \\
\text { навчання своїх дітей }\end{array}$ & $\begin{array}{l}\text { • вища ймовірність зменшен- } \\
\text { ня дітності сімей у зв’язку } \\
\text { з відтермінуванням народ- } \\
\text { ження; } \\
\text { • старші подружжя частіше } \\
\text { обирають бездітний спосіб } \\
\text { життя з огляду на значний } \\
\text { розмір альтернативних ви- } \\
\text { трат, пов'язаних з народжен- } \\
\text { ням і вихованням дітей }\end{array}$ \\
\hline $\begin{array}{l}\text { Зменшення середньої } \\
\text { тривалості шлюбу }\end{array}$ & $\begin{array}{l}\text { • розпад неблагополучних шлюбів } \\
\text { зменшує негативний вплив на } \\
\text { дитячу психіку, викликаний } \\
\text { родинними негараздами; } \\
\text { • у нових шлюбах можуть бути } \\
\text { створені кращі умови для ви- } \\
\text { ховання та розвитку дітей }\end{array}$ & $\begin{array}{l}\text { • виникнення неповних } \\
\text { сімей, можлива деформація } \\
\text { психологічного розвитку } \\
\text { дитини за умови виховання } \\
\text { без одного з батьків; } \\
\text { • погіршення матеріального } \\
\text { добробуту у сім’ях, де пра- } \\
\text { цює один з батьків }\end{array}$ \\
\hline $\begin{array}{l}\text { Поступове зростання } \\
\text { ролі батька у вихованні } \\
\text { дітей }\end{array}$ & $\begin{array}{l}\text { • зниження гендерної нерівності; } \\
\text { • підвищення авторитету батька; } \\
\text { • активніше залучення чоловіка до } \\
\text { виконання домашніх обов’язків }\end{array}$ & $\begin{array}{l}\text { - жінки повинні більше часу } \\
\text { приділяти роботі, щоб } \\
\text { зберегти необхідний рівень } \\
\text { доходів (за умови, якщо } \\
\text { чоловік працює менше) }\end{array}$ \\
\hline $\begin{array}{l}\text { Зростання економічної } \\
\text { активності жінок }\end{array}$ & $\begin{array}{l}\text { • у сім’ях, в яких працюють двоє } \\
\text { членів подружжя, вищий рівень } \\
\text { матеріального добробуту, відпо- } \\
\text { відно кращі умови для вихован- } \\
\text { ня дітей }\end{array}$ & $\begin{array}{l}\text { • досить часто жінки беруть на } \\
\text { себе функцію «годувальни- } \\
\text { ка», що може призвести до } \\
\text { конфліктів у сім’ї; } \\
\text { • жінки приділяють менше } \\
\text { уваги дітям, менше часу } \\
\text { інвестують у їхній розвиток }\end{array}$ \\
\hline
\end{tabular}


Як видно з дослідження європейських сімейних цінностей, для України та країн Східної Європи більш характерними є традиційні сімейні цінності, діти мають велике значення, як для жінки, так і для чоловіка. Проте в нашій країні відбувається поступовий перехід до західної системи цінностей, про що свідчать сучасні тенденції у батьківстві (табл. 1). Нами проаналізовані можливі соціально-економічні наслідки цих тенденцій та їхній вплив на соціально-демографічну ситуацію.

Як бачимо, сучасні тенденції у батьківстві мають Як позитивні, так і негативні соціально-демографічні наслідки, зупинити трансформацію суспільних цінностей практично неможливо, проте важливо інструментами соціальної політики максимально забезпечити ретрансляцію традиційних цінностей українського суспільства.

Для оцінювання динаміки явищ та процесів у царині відповідального батьківства в Україні пропонуємо використовувати систему показників, які дають змогу оцінити наявний стан та зрушення у цій сфері (табл. 2). При виборі показників ми керувались

Таблиия 2. Показники для оцінювання основних форм відповідального батьківства

\begin{tabular}{|c|c|}
\hline $\begin{array}{c}\text { Форми прояву відповідаль- } \\
\text { ного батьківства }\end{array}$ & Показники для оцінювання відповідального батьківства \\
\hline Репродуктивна поведінка & $\begin{array}{l}\text { Показники репродуктивного здоров’я: } \\
\text { • поширеність хвороб, що передаються статевим шляхом; } \\
\text { • вік, у якому відбувся перший сексуальний контакт; } \\
\text { • кількість сексуальних партнерів до вступу в шлюб; } \\
\text { • рівень безпліддя (за обома статями) }\end{array}$ \\
\hline $\begin{array}{l}\text { Ставлення до вагітності/ } \\
\text { відповідальність за здорове } \\
\text { потомство }\end{array}$ & $\begin{array}{l}\text { • рівень поінформованості про засоби контрацепції; } \\
\text { - рівень і структура використання контрацептивів; } \\
\text { • частота абортів; } \\
\text { • співвідношення абортів та пологів; } \\
\text { • частка жінок, вагітність яких проходить з ускладненнями; } \\
\text { - частка партнерських пологів; } \\
\text { • рівень смертності немовлят; } \\
\text { - частка дітей, народжених з ВІЛ }\end{array}$ \\
\hline Вітальна поведінка & $\begin{array}{l}\text { • частка осіб, які палять; } \\
\text { • частка осіб, які вживають наркотичні речовини; } \\
\text { • частка осіб, які зловживають алкоголем; } \\
\text { • частка осіб, які ведуть активний спосіб життя та займаються } \\
\text { спортом; } \\
\text { - частка осіб, які харчуються відповідно до принципів здорового } \\
\text { харчування }\end{array}$ \\
\hline Виховання дітей & $\begin{array}{l}\text { • час, який батьки приділяють дитині; } \\
\text { • витрати сім'ї на утримання дітей; } \\
\text { • витрати сім'ї на виховання та розвиток дітей; } \\
\text { • витрати сім'ї на спільний з дітьми відпочинок та розваги; } \\
\text { • інвестиції в освіту дитини; } \\
\text { • показники стану здоров’я дітей }\end{array}$ \\
\hline $\begin{array}{l}\text { Особисті комунікації в до- } \\
\text { рослому віці }\end{array}$ & $\begin{array}{l}\text { • час, який приділяють бабусі та дідусі вихованню онуків; } \\
\text { • грошові трансферти від дітей батькам у старшому віці }\end{array}$ \\
\hline
\end{tabular}


наявною інформаційною-статистичною базою. Для вивчення репродуктивної та вітальної поведінки доцільно використовувати наявні медико-соціальні обстеження, дані Центру медичної статистики, дані Міністерства охорони здоров'я. Відомості щодо часу, який батьки та родичі приділяють вихованню дітей, можна отримати зі спеціальних обстежень, проведених міжнародними організаціями (напр. ЮНІСЕФ). Загалом, системне дослідження відповідального батьківства потребує грунтовного збору та аналізу даних із різних джерел.

Висновки та перспективи подалыших досліджень. Відповідальне батьківство - це платформа, на основі якої формуються виважена потреба в дітях, необхідні знання для виховання та розвитку дітей, партнерські стосунки між батьками й дітьми протягом життя. Це багатогранне явище, яке розкривається через етичний, правовий, соціальний та економічний виміри, та є синтезом відповідальної репродуктивної та вітальної поведінки, відповідального ставлення до вагітності та пологів, відповідального виховання дітей та регулярних позитивних комунікацій у родині.

Для становлення інституту відповідального батьківства вкрай важливим є розвиток суміжних інститутів, як-то: інфраструктура, необхідна для народження та виховання дітей, лібералізація трудового законодавства, яка дала б змогу як жінкам, так і чоловікам більше часу приділяти сім'ї та вихованню дітей. Тобто, коли ми говоримо про відповідальне батьківство, ми також повинні говорити про відповідального роботодавця і відповідальну державу.

Окрім важливої соціальної складової, батьківство має важливу економічну складову. Безумовно, народження та виховання дітей вимагає фінансових вкладень, проте батьки окрім прямих видатків несуть інші втрати, пов'язані з батьківством. У перспективі подальших досліджень вивчення фінансових втрат від батьківства та материнства у розрізі трудових доходів, тобто аналіз того, яким чином наявність дітей впливає на доходи матері та батька у порівнянні з тими, у кого немає дітей.

\section{ЛІТЕРАТУРА}

1. Думанська В.П. Монетарний пронаталізм: оцінка ефективності / В.П. Думанська // Демографія і соціальна економіка. - 2013. - №1 (19). - С. 28-36. - doi : 10.15407/dse2013.01.028

2. Кример Б.О. Демографічні результати запровадження допомоги при народженні дитини / Б.О. Кример // Демографія і соціальна економіка. - 2013. - №1 (19). - С. 37-46. - doi : 10.15407/ dse2013.01.037

3. Овчарова Р. В. Психология родительства : учеб. пособие для студентов / Р. В. Овчарова.- М. : Академия, 2005. - $368 \mathrm{c.}$

4. Офіційний сайт UNICEF [Електронний ресурс]. - Режим доступу : http://www.unicef.org/earlychildhood/index_69849.html

5. Шлюб, сім’я і дітородні орієнтації в Україні : [колективна монографія] / Наук. кер. Лібанова Е.М. - К. : АДЕФ-Україна, 2008. - 256 с.

6. European Values Studies. Family section. [Електронний ресурс]. - Режим доступу : http://www. europeanvaluesstudy.eu/frmShowpage?v_page_id=7461989851426413

7. Feeney J. Becoming Parents: Exploring the Bonds Between Mothers, Fathers, and Their Infants. Cambridge University Press, 2001. - 248 p.

8. Gornick J.C., Meyers M.K. Families That Work: Policies for Reconciling Parenthood and Employment. Russell Sage Foundation, 2003. - 404 p.

9. Halman L., Sieben I., Van Zundert M. Atlas of European Values: Trends and Traditions at the turn of the Century. - Leiden, the Netherlands: Brill. 2011.

10. Lundberg S., Rose E. Parenthood and the Earnings of Married Men and Women // Labour Economics. 7, Is. 6. (November). - 2000. - P. 689-710. 
11. Van de Kaa, Dirk. J. Europe's Second Demographic Transition // Population Bulletion. - 1987. - 42 (1). - P . 1-47.

\section{REFERENCES}

1. Dumanska, V.P. (2013). Monetarnyy pronatalizm: otsinka efektyvnosti [Monetary protanalizm: performance evaluation]. Demohrafiya i sotsial na ekonomika - Demography and social economy, 1(19), 28-36 [in Ukrainian]. doi : 10.15407/dse2013.01.028

2. Krymer, B.O. (2013). Demohrafichni rezul'taty zaprovadzhennya dopomohy pry narodzhenni dytyny [The demographic results of the government children support]. Demohrafiya i sotsialna ekonomika Demography and social economy, 1 (19), 37-46 [in Ukrainian]. doi : 10.15407/dse2013.01.037

3. Ovcharova, R. V. (2005). Psykholohyya rodytel'stva: ucheb. posobye dlya studentov [Psychology of parenthood: a manual for students]. Moskva: Akademyya [in Russian].

4. Sait UNICEF [Site of the UNICEF]. unicef.org. Retrived from: http://www.unicef.org/earlychildhood/index 69849.html [in English].

5. Libanova E. M. (Ed.) (2008). Shlyub, sim'ya ta ditorodni oriyentatsiyi v Ukrayini [Marriage, childbearing and family orientation in Ukraine]. Kyiv: ADEF-Ukrayina [in Ukrainian].

6. Site research program European Values Studies. Family section. europeanvaluesstudy.eu. Retrived from: http://www.europeanvaluesstudy.eu/frmShowpage?v_page_id=7461989851426413 [in English].

7. Feeney J. (2001). Becoming Parents: Exploring the Bonds Between Mothers, Fathers, and Their Infants. Cambridge University Press.

8. Gornick J.C., Meyers M.K. (2003). Families That Work: Policies for Reconciling Parenthood and Employment. Russell Sage Foundation.

9. Halman L., Sieben I., Van Zundert M. (2011). Atlas of European Values: Trends and Traditions at the turn of the Century. Leiden, the Netherlands: Brill.

10. Lundberg S., Rose E. (2000). Parenthood and the Earnings of Married Men and Women Labour Economics Volume 7, Issue 6, 689-710.

11. Van de Kaa, Dirk. J. (1987). Europe's Second Demographic Transition. Population Bulletion 42(1), $1-47$.

Стаття надійшла до редакції журналу 30.07.2015. 